\title{
Sexual dimorphism in glucose and lipid metabolism during fasting, hypoglycemia, and exercise
}

\author{
Maka S. Hedrington and Stephen N. Davis * \\ Department of Medicine, University of Maryland, Baltimore, MD, USA
}

Sexually dimorphic physiologic responses occur during fasting, hypoglycemia, and exercise. The areas covered in this mini review include studies that have used isotopic tracer methods and/or euglycemic clamp studies to investigate substrate metabolism during the above common physiologic stress. Women have greater reliance on lipid metabolism during fasting, hypoglycemia, and exercise while men exhibit preference of carbohydrate utilization. Plasma glucose concentrations were shown to be lower, while free fatty acids (FFA) and lipolysis higher in women compared to men after fasting. Hypoglycemia resulted

OPEN ACCESS

Edited by:

Janne Lebeck

Danish Diabetes Academy, Denmark

Reviewed by:

Marek Bolanowski,

Wroclaw Medical University, Poland

Søren Nielsen,

Aarhus University Hospital, Denmark

*Correspondence:

Stephen N. Davis,

Department of Medicine, University of Maryland School of Medicine, 22 South Greene Street, Room N3W42,

Baltimore, MD 21201, USA

sdavis@medicine.umaryland.edu

Specialty section:

This article was submitted to Diabetes, a section of the journal

Frontiers in Endocrinology

Received: 11 February 2015

Paper pending published:

23 March 2015

Accepted: 08 April 2015

Published: 27 April 2015

Citation:

Hedrington MS and Davis SN (2015)

Sexual dimorphism in glucose and lipid metabolism during fasting,

hypoglycemia, and exercise.

Front. Endocrinol. 6:61.

doi: 10.3389/fendo.2015.00061 in significantly reduced epinephrine, norepinephrine, glucagon, growth hormone, pancreatic polypeptide, and hepatic glucose production responses in females as compared to males. Sexual dimorphism during exercise was demonstrated by higher glycerol and FFA responses in women compared to men and higher carbohydrate oxidation rate in men. Mechanisms that can increase lipolytic rates in women include higher total fat mass, enhanced lipolytic sensitivity to epinephrine, and increased activation of $\beta$ adrenergic receptors.

Keywords: exercise, fasting, glucose, hypoglycemia, lipids, metabolism

\section{Introduction}

Physiologic responses to fasting, hypoglycemia, or exercise include activation of critical homeostatic (counterregulatory) mechanisms to maintain or restore euglycemia. These mechanisms include a series of autonomic nervous system (ANS), neuroendocrine and metabolic responses that increase glucose availability by stimulating initially hepatic (later renal) glycogenolysis and gluconeogenesis and enhanced lipolysis. Increased peripheral glycogenolysis provides three carbon precursors such as lactate and pyruvate for gluconeogenesis. Lipolysis generates glycerol as another important gluconeogenic substrate and free fatty acids (FFA) as energy that drives the process. Proteolysis also produces substrates (amino acids) for the gluconeogenic process. Although these are general responses in both sexes, there appears to be significant quantitative gender-based differences in substrate utilization. A number of studies have demonstrated preference of carbohydrate metabolism in men and lipid in women.

Understanding the sexual dimorphism present in fuel oxidation during different metabolic states could contribute to the development of improved and specific gender-based nutritional guidelines such as during exercise programs. For individuals with diabetes, preventive and therapeutic strategies modified for each gender could, potentially, assist in achieving and sustaining target glycemia.

In this mini review, we will discuss sexual dimorphism in glucose and lipid metabolism during different metabolic states while concentrating on in vivo mechanistic studies that have used 
isotopic tracer methods and/or hyperinsulinemic glucose clamp studies to investigate gender-based differences in substrate metabolism during fasting, hypoglycemia, or exercise.

\section{Fasting}

General responses to fasting are gender-neutral, and include increases in plasma fatty acid and ketones, and a decrease in plasma glucose concentrations (1). However, the decrement in glucose and surge in lipids is significantly greater in women than in men.

The gender-related differences start appearing even during short-term calorie restriction and become prominent during prolonged fasting $(2,3)$. Mittendorfer et al. studied whole body lipid and glucose kinetics during basal (14h) and short-term (22 h) fasting in healthy men and women matched for percent body fat (3). Isotope labeled tracers of glucose $\left(\left[{ }^{2} \mathrm{H}_{2}\right]\right.$ glucose $)$ and glycerol $\left(\left[{ }^{2} \mathrm{H}_{5}\right]\right.$ glycerol $)$ were used to measure substrate kinetics. The study demonstrated that women had a greater basal glycerol rate of appearance $(\mathrm{Ra})$, which is an index of whole body lipolytic rate (women: $2.1 \mu \mathrm{mol} \cdot \mathrm{kg}$ body $\mathrm{wt}^{-1} \cdot \mathrm{min}^{-1}$ vs. men: $1.5 ; p<0.05$ ). Glucose kinetics ( $\mathrm{Ra}$ and $\mathrm{Rd}$ ) appeared to be similar between the groups. Thus, metabolic changes during basal and short term fasting involved a sexual dimorphism in lipid but not glucose metabolism. Two major regulators of lipolysis: insulin (inhibition) and epinephrine (stimulation) were suggested to be related to the reported metabolic changes. Insulin was numerically lower in women compared to men (women: $6 \mu \mathrm{U} / \mathrm{ml}$ vs. men: 9), while epinephrine concentration during $14-22 \mathrm{~h}$ of fasting was significantly higher in men (women: $57 \mathrm{pg} / \mathrm{ml}$ vs. men: 23 ; $p<0.05$ ). Since there was no difference in glucose production between the genders, the lower insulin concentration could suggest increased hepatic insulin action in women compared to men under shortterm fasting conditions.

Greater gender-based metabolic differences were demonstrated during more prolonged fasting (38-72 h) (4-7). Plasma glucose concentrations were lower after $38 \mathrm{~h}$ of fasting (4) (women: $3.9 \mathrm{mmol} / \mathrm{l}$ vs. men: $4.4 ; p=0.02$ ), while FFA (women: $1.3 \mathrm{mmol} / \mathrm{l}$ vs. men: $1 ; p<0.02$ ) and lipolysis (women: $259 \mu \mathrm{mol} / \mathrm{kcal}$ vs. men: $194 ; p=0.004)$ were higher in women compared to men. About $72 \mathrm{~h}$ of fasting resulted in significantly higher plasma glycerol levels in women $(0.2 \mathrm{mmol} / \mathrm{l}, p<0.05)$ compared with men $(0.1 \mathrm{mmol} / \mathrm{l})$ (6). Merimee et al. (7) also investigated metabolic changes during $72 \mathrm{~h}$ fast and reported that the plasma glucose level fell to $66 \mathrm{mg} / \mathrm{dl}$ in men and $48 \mathrm{mg} / \mathrm{dl}$ in women $(p<0.01)$, and the mean peak FFA concentration was $2.3 \mathrm{mmol} / \mathrm{l}$ in women and only $1.4 \mathrm{mmol} / \mathrm{l}$ in men $(p<0.01)$. Gender-based differences in FFA kinetics were demonstrated in 106 healthy subjects (8). The study showed that total FFA $\mathrm{Ra}$ and FFA $\mathrm{Ra}$ with respect to fatfree mass were greater in women than in men. This dimorphism was explained by the differences in body composition between genders (i.e., more body fat in women).

Possible explanations for the observed gender-based differences in lipid mobilization could include sexually dimorphic changes in anatomic fat distribution (9). Men have a higher distribution of visceral fat and women have greater lower body and subcutaneous fat. Lower body fat has been demonstrated to exhibit greater lipolytic rates resulting in higher plasma FFA concentration compared to men $(4,10-12)$. Interestingly, visceral adipose tissue is responsible for greater hepatic FFA delivery in women than in men and the effect increases with increasing visceral fat (13). Subcutaneous fat has a greater leptin expression rate compared to visceral adipose tissue (14). Leptin is a "satiety hormone" that regulates the amount of fat stored in the body and women have been demonstrated to have two to three times higher levels compared to men $(14,15)$. This has led to the speculation that adipose tissue in women is somewhat resistant to leptin's lipogenic actions. However, two other studies, both by Jensen et al. (16), demonstrated that the association between plasma leptin concentration and percent body fat was similar in both genders. Thus, the role of leptin sensitivity in men and women remains unclear.

Several studies have reported improved insulin sensitivity in women and suggested insulin's role in sexually dimorphic metabolic changes (17-22). However, in these studies, the influence of the menstrual cycle was either not considered or women were studied during follicular phase when insulin sensitivity is increased $(23,24)$. Many other studies showed no difference in insulin sensitivity between genders $(4,25-31)$. Therefore, the effects of insulin action on gender-specific metabolic changes remain controversial.

\section{Hypoglycemia}

The hypoglycemic clamp technique produces a standardized decrease in plasma glucose and stable glycemic plateau (32). Controlling the rate of fall of plasma glucose or the period of hyperinsulinemic euglycemia immediately before inducing hypoglycemia has been reported to affect the magnitude of neuroendocrine responses during hypoglycemia. Additionally, the magnitude of counterregulatory responses doubles for each $10 \mathrm{mg} / \mathrm{dl}$ decrement in plasma glucose below $70 \mathrm{mg} / \mathrm{dl}$.

We have previously investigated gender-related differences in ANS, neuroendocrine and metabolic counterregulatory responses during hypoglycemia, and the physiologic mechanisms that determine those differences (33-37). We have reported that large sexual dimorphisms exist in counterregulatory responses during both a single episode of hypoglycemia and following repeated hypoglycemia (Figure 1). We have also described the role of CNS drive in triggering gender differences in metabolic responses and estrogen's role in regulating ANS, neuroendocrine and metabolic responses to hypoglycemia.

Gender-specific changes during a single-step 2-h hyperinsulinemic hypoglycemic clamp of $50 \mathrm{mg} / \mathrm{dl}$ were investigated in age and BMI matched males and females (34). Data obtained during the steady-state period at the end of clamps demonstrated significant sexual dimorphism in neuroendocrine and metabolic responses to hypoglycemia. Epinephrine (women: $5.7 \mathrm{nM}$ vs. men: $8.8 ; p<0.05$ ), norepinephrine (women: $2.6 \mathrm{nM}$ vs. men: 3.3 ; $p<0.05$ ), glucagon (women: $127 \mathrm{ng} / \mathrm{l}$ vs. men: $215 ; p<0.05$ ), growth hormone (women: $36 \mu \mathrm{g} / \mathrm{l}$ vs. men: 53 ; $p<0.05$ ), pancreatic polypeptide (women: $144 \mathrm{pM}$ vs. men: $291 ; p<0.05$ ), and hepatic glucose production (women: $9.5 \mu \mathrm{mol} / \mathrm{kg} / \mathrm{min}$ vs. men: $18.1 ; p<0.05)$ responses were significantly reduced in females 


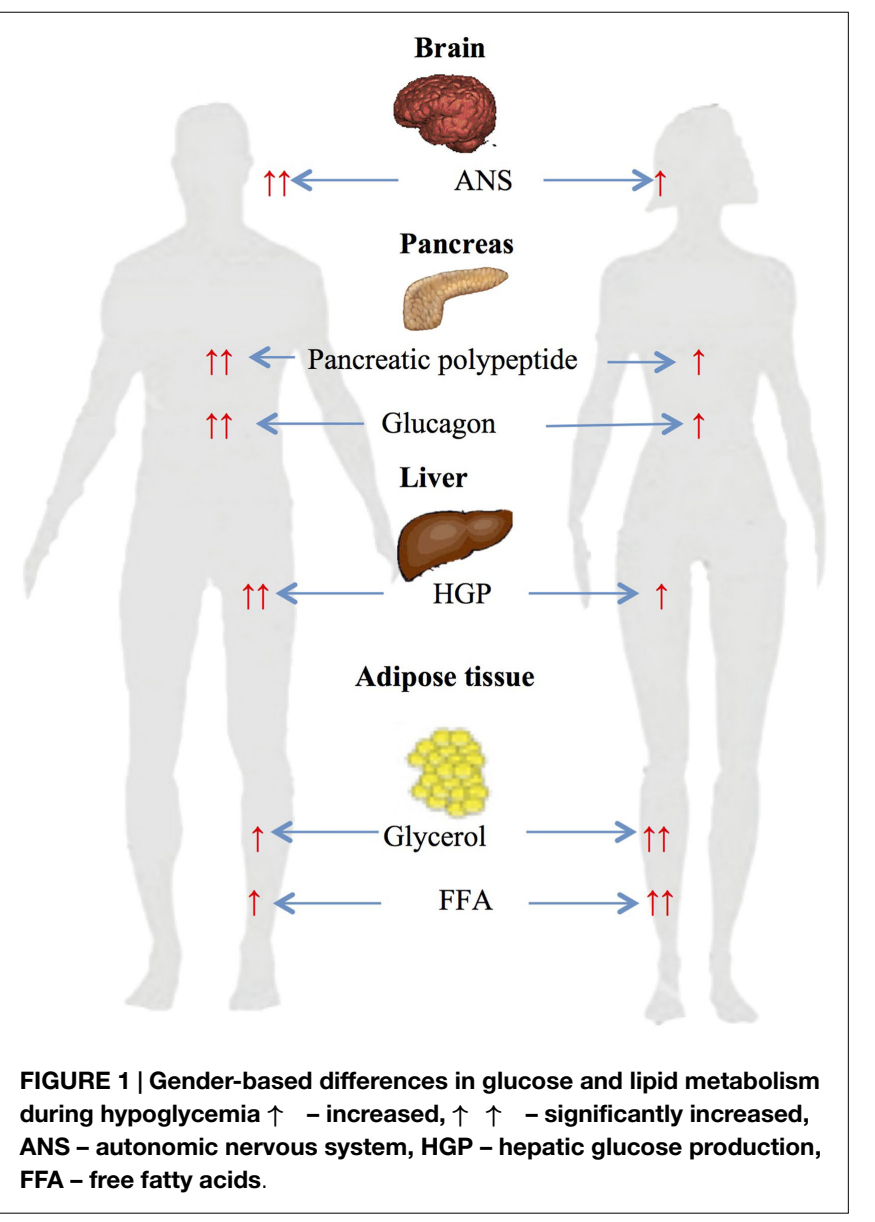

compared to males. Diamond et al. (38) and Amiel et al. (39) have also demonstrated similar sexual dimorphisms in neuroendocrine counterregulatory responses during hypoglycemia in males and females.

It was investigated whether gender-based differences in metabolic changes observed in healthy subjects (described above) also occur in individuals with type 1 diabetes (37). The study demonstrated that women with type 1 diabetes (similar to healthy women) had significantly reduced neuroendocrine (growth hormone - women: $15 \mu \mathrm{g} / \mathrm{l}$ vs. men: 25; $p<0.05$ ), ANS (epinephrine - women: $2.6 \mathrm{nmol} / 1$ vs. men: 5 ; norepinephrine women: $1.7 \mathrm{nmol} / \mathrm{l}$ vs. men: $2.3 ; p<0.05)$, endogenous glucose production (women: $3.9 \mu \mathrm{mol} \cdot \mathrm{kg}^{-1} \cdot \mathrm{min}^{-1}$ vs. men: 9.4, $p<0.01$ ), and cardiovascular (mean arterial pressure - women: $75 \mathrm{mmHg}$ vs. men: 83 ; $p<0.01$ ) responses to moderate hypoglycemia compared to men. The above study demonstrated that significant neuroendocrine and metabolic sexual dimorphisms exist in responses to hypoglycemia in individuals with type 1 diabetes.

In searching for the cause of sexually dimorphic counterregulatory responses during hypoglycemia, several mechanisms have been proposed. One plausible explanation was that differences in the neuroendocrine responses may have been due to differential glycemic thresholds. A glycemic threshold is defined as the plasma glucose level at which counterregulatory hormones are released. Thus, 15 lean healthy men and women were studied during separate randomized single step hyperinsulinemic glucose clamp studies at euglycemia $(90 \mathrm{mg} / \mathrm{dl})$ or hypoglycemia of 70 , 60 , or $50 \mathrm{mg} / \mathrm{dl}$ (33). The study demonstrated that the magnitude of physiological counterregulatory responses that affect glucose and lipid metabolism were reduced in healthy women compared to men during each discreet level of hypoglycemia. However, the cause of this dimorphism did not appear to be differential glycemic thresholds as both sexes demonstrated similar plasma glucose levels at which counterregulatory mechanisms were activated (epinephrine, glucagon, growth hormone, cortisol, and pancreatic polypeptide - 70-79 mg/dl; muscle sympathetic nerve activity - 60-69 $\mathrm{mg} / \mathrm{dl}$; and norepinephrine $50-59 \mathrm{mg} / \mathrm{dl})$. The finding that direct sympathetic nerve activity as well as hypothalamo-pituitary responses were reduced during hypoglycemia point to a reduced central nervous system efferent response as a more likely mechanism for the sexually dimorphic counterregulatory responses occurring during hypoglycemia.

Another plausible mechanism for gender-based differences in substrate metabolism involves female reproductive hormones. Estrogen has been demonstrated to reduce lipolysis and plasma catecholamine concentration by either inhibiting secretion or accelerating degradation $(40,41)$. To investigate estrogen's role in counterregulatory differences between genders during hypoglycemia, postmenopausal women on estrogen replacement were compared with postmenopausal women who did not receive replacement therapy and with age and BMI matched men during a single episode of hypoglycemia (35). Postmenopausal women on estrogen replacement were found to have reduced (epinephrine, muscle sympathetic nerve activity, pancreatic polypeptide, glucagon, endogenous glucose production, lactate, and glycerol) counterregulatory responses to hypoglycemia as compared to the similarly increased responses in women who were not on the replacement therapy and men. Thus, estrogen appears to play a significant role in the gender-based premenopausal differences in hypoglycemia-induced counterregulatory responses.

Interestingly, despite the above neuroendocrine and ANS responses, glycerol was reported to be higher in females compared to males during hypoglycemia $(33,34,37)$. The differences could be attributed to a greater glycerol turnover rate due to increased peripheral fat accumulation and higher percent fat mass in females. Another reasonable explanation is higher sensitivity of the female adipose tissue to lipolytic hormones (epinephrine, norepinephrine, growth hormone). In fact, women have been shown to be more sensitive to epinephrine-induced lipolysis compared to men (42-44). Schmidt et al. investigated contribution of specific adrenergic receptor(s) in mediating gender-related differences in metabolic responses (44). The study demonstrated that infusion of epinephrine resulted in greater increases in glycerol, FFA, and palmitate $\mathrm{Ra}$ and $\mathrm{Rd}$ per kilogram body weight in women compared to men. Thus, in states of high epinephrine concentrations (e.g., hypoglycemia), women would be predicted to exhibit higher lipolysis and fat oxidation.

In addition to the gender-based differences during a single bout of hypoglycemia, we have also investigated the impact of antecedent hypoglycemia on subsequent counterregulatory responses (36). Surprisingly, women appeared to be more resistant 
to the blunting effects of repeated hypoglycemia on ANS, neuroendocrine and metabolic counterregulatory responses. In fact, repeated hypoglycemia produced nearly twofold greater suppressive effects on counterregulatory responses in men as compared to women. Thus, after two prior episodes of moderate hypoglycemia $(50 \mathrm{mg} / \mathrm{dl})$, the usual large sexual dimorphism in counterregulatory responses was lost during a next day episode of hypoglycemia. In other words, following day 1 hypoglycemia, counterregulatory responses were equivalent during next day subsequent hypoglycemia. This finding may help explain the finding why intensive glycemic control in younger women with type 1 diabetes results in fewer episodes of severe hypoglycemia compared to men.

\section{Exercise}

A number of studies have investigated gender-based differences in metabolic changes during differing exercise work intensities (Figure 2).

Several studies from our own and other laboratories have assessed gender differences during $90 \mathrm{~min}$ of moderate-intensity $(\approx 50 \%$ VO2 max) cycle ergometer exercise $(45,46)$. The studies demonstrated significantly higher glycerol and FFA responses in women compared to men and higher carbohydrate oxidation rate in men (45). Plasma FFA during exercise has been reported to be produced from differing anatomical sites in women and men (47-49). Roepstorff et al. demonstrated high myocellular

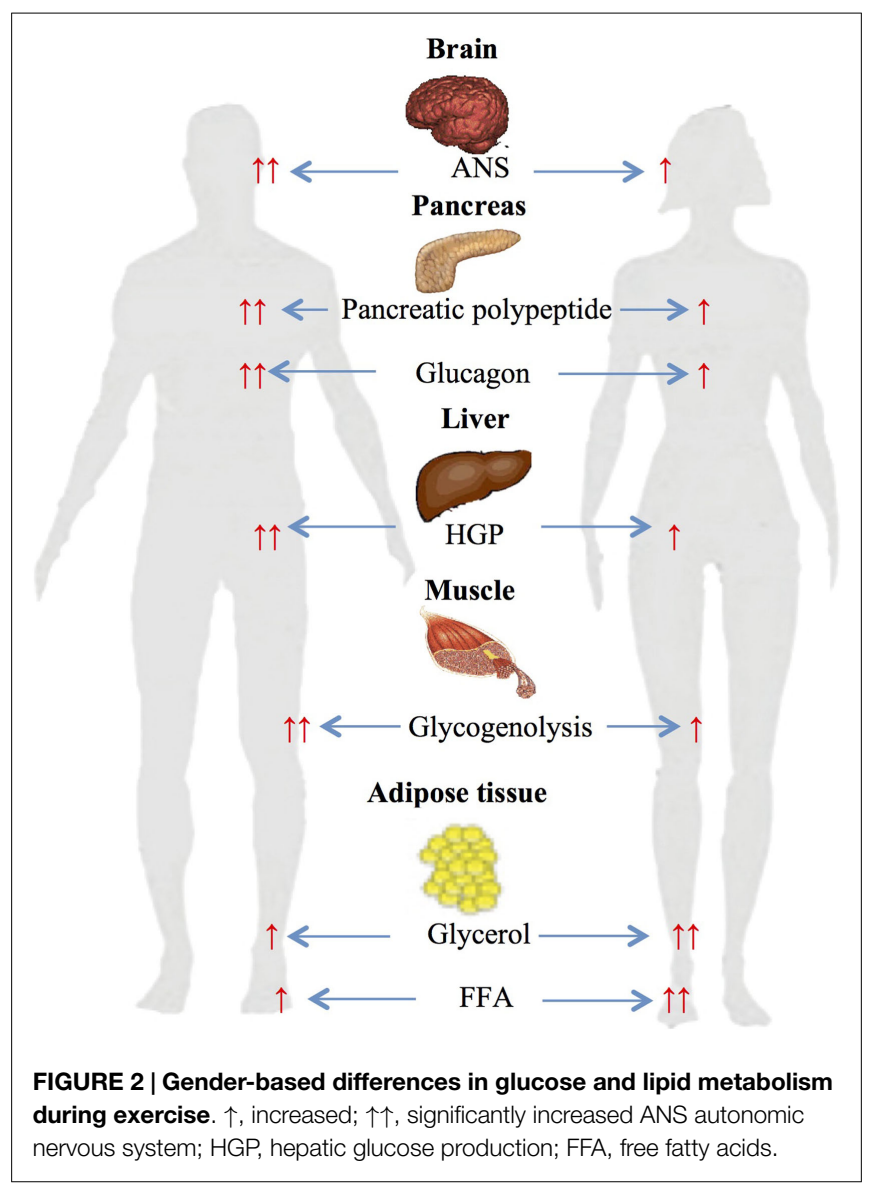

triacylglycerol degradation in women compared to negligible in men during submaximal exercise. This was explained by higher basal intramyocellular triacylglycerol in women compared with men $(48,49)$. Steffensen et al. also reported similar results when measuring myocellular triacylglycerol in 21 females and 21 males during rest and exercise, and demonstrated $\approx 25 \%$ decrease in myocellular triacylglycerol content in females during exercise and no change in males (47).

Effects of long duration ( $2 \mathrm{~h}$ ) exercise at $40 \% \mathrm{VO} 2 \mathrm{max}$ and post exercise substrate metabolism were studied in 27 healthy individuals (50). During exercise, women demonstrated higher fat oxidation $(51 \%, p<0.02)$ compared with men $(44 \%)$. Men, on the other hand, had significantly higher circulating catecholamines and greater carbohydrate oxidation $(53 \%, p<0.01)$ than women $(46 \%)$. There were no differences between the genders in fuel metabolism before or after ( $2 \mathrm{~h}$ recovery period) exercise. Similar metabolic differences between genders were reported in a study that investigated 7 weeks of endurance training (51). General adaptive changes to endurance training - decrease in muscle carbohydrate utilization and increase in lipid oxidation were present in both sexes; however, consistent with other exercise studies, women utilized more lipid and men increased carbohydrates during exercise. Thus duration and intensity of the exercise did not change gender-based differences in substrate metabolism during exercise.

To investigate the mechanisms for gender-specific responses during exercise, healthy women during the follicular and luteal phases of the menstrual cycle and healthy men were studied during 90-min cycling exercise at $65 \% \mathrm{VO} 2 \mathrm{max}$ (52). [6,6$2 \mathrm{H}$ ]glucose was used to calculate glucose kinetics, which were significantly different between women in each phase of the menstrual cycle and between men and women. Women in the luteal phase had lower glucose $\mathrm{Ra}\left(49 \mu \mathrm{mol} \cdot \mathrm{kg}^{-1} \cdot \mathrm{min}^{-1} ; p=0.03\right)$, Rd $\left(49 \mu \mathrm{mol} \cdot \mathrm{kg}^{-1} \cdot \mathrm{min}^{-1} ; p=0.03\right)$, and metabolic clearance rate $\left(10 \mathrm{ml} \cdot \mathrm{kg}^{-1} \cdot \mathrm{min}^{-1} ; p=0.04\right)$ at $90 \mathrm{~min}$ of exercise compared with women in follicular phase $\left(52 \mu \mathrm{mol} \cdot \mathrm{kg}^{-1} \cdot \mathrm{min}^{-1}\right.$, $52 \mu \mathrm{mol} \cdot \mathrm{kg}^{-1} \cdot \mathrm{min}^{-1}, 9 \mathrm{ml} \cdot \mathrm{kg}^{-1} \cdot \mathrm{min}^{-1}$, respectively). Women, regardless of the menstrual cycle, had a lower respiratory exchange ratio, glucose $\mathrm{Ra}$ and $\mathrm{Rd}$, and metabolic clearance rate during exercise compared with men $(p<0.05)$. During the study, muscle biopsies were taken to investigate muscle glycogen utilization. Women in the luteal phase had lower proglycogen $(p=0.04)$, macroglycogen $(p=0.04)$, and total glycogen $(p=0.02)$ use during exercise compared with women in follicular phase. Thus female reproductive hormones appear to play an important role in muscle sparing of glycogen utilization. Adding to this finding, biopsy samples from skeletal muscle, heart, and liver in estradiol treated rats demonstrated reduced glycogen metabolism compared to non-treated male rats $(53,54)$.

The above studies clearly demonstrate that women have reduced carbohydrate and increased lipid utilization compared to men. The sexually dimorphic changes in ANS responses appear to be a major contributor to these metabolic findings. Women during exercise had significantly lower circulating epinephrine and norepinephrine that are known to stimulate muscle glycogenolysis and carbohydrate oxidation $(45,55,56)$. Second, the finding of increased lipid metabolism can be explained 
by sexually dimorphic stimulation of adrenergic receptors: while both adrenoreceptors ( $\alpha$ and $\beta$ ) are activated in men during exercise, women have been shown to depend solely on $\beta$ receptors (57, 58). Since $\alpha$ adrenoreceptors inhibit while $\beta$ stimulate lipolysis, this would result in net greater lipolysis in women (45).

\section{Conclusion}

Short-term fasting (14-22 h) resulted in sexually dimorphic metabolic changes, which were more pronounced during prolonged fasting (38-72 h): lipid metabolism was reported to be higher and carbohydrate utilization lower in women compared to men.

Neuroendocrine, ANS, and metabolic responses during hypoglycemia were nearly twofold greater in men compared to age matched premenopausal women. Metabolic changes during

\section{References}

1. Maughan RJ, Fallah J, Coyle EF. The effects of fasting on metabolism and performance. Br J Sports Med (2010) 44(7):490-4. doi:10.1136/bjsm.2010. 072181

2. Browning JD, Baxter J, Satapati S, Burgess SC. The effect of short-term fasting on liver and skeletal muscle lipid, glucose, and energy metabolism in healthy women and men. J Lipid Res (2012) 53(3):577-86. doi:10.1194/jlr.P020867

3. Mittendorfer B, Horowitz JF, Klein S. Gender differences in lipid and glucose kinetics during short-term fasting. Am J Physiol Endocrinol Metab (2001) 281(6):E1333-9.

4. Soeters MR, Sauerwein HP, Groener JE, Aerts JM, Ackermans MT, Glatz JF, et al. Gender-related differences in the metabolic response to fasting. J Clin Endocrinol Metab (2007) 92(9):3646-52. doi:10.1210/jc.2007-0552

5. Haymond MW, Karl IE, Clarke WL, Pagliara AS, Santiago JV. Differences in circulating gluconeogenic substrates during short-term fasting in men, women, and children. Metabolism (1982) 31(1):33-42. doi:10.1016/0026-0495(82) 90024-5

6. Clore JN, Glickman PS, Helm ST, Nestler JE, Blackard WG. Accelerated decline in hepatic glucose production during fasting in normal women compared with men. Metabolism (1989) 38(11):1103-7. doi:10.1016/0026-0495(89)90047-4

7. Merimee TJ, Fineberg SE. Homeostasis during fasting. II. Hormone substrate differences between men and women. J Clin Endocrinol Metab (1973) 37(5):698-702. doi:10.1210/jcem-37-5-698

8. Mittendorfer B, Magkos F, Fabbrini E, Mohammed BS, Klein S. Relationship between body fat mass and free fatty acid kinetics in men and women. Obesity (2009) 17(10):1872-7. doi:10.1038/oby.2009.224

9. Lemieux S, Prud'homme D, Bouchard C, Tremblay A, Despres JP. Sex differences in the relation of visceral adipose tissue accumulation to total body fatness. Am J Clin Nutr (1993) 58(4):463-7.

10. Frayn KN, Karpe F, Fielding BA, Macdonald IA, Coppack SW. Integrative physiology of human adipose tissue. Int J Obes Relat Metab Disord (2003) 27(8):875-88. doi:10.1038/sj.ijo.0802326

11. Macotela Y, Boucher J, Tran TT, Kahn CR. Sex and depot differences in adipocyte insulin sensitivity and glucose metabolism. Diabetes (2009) 58(4):803-12. doi:10.2337/db08-1054

12. Jensen MD, Johnson CM. Contribution of leg and splanchnic free fatty acid (FFA) kinetics to postabsorptive FFA flux in men and women. Metabolism (1996) 45(5):662-6. doi:10.1016/S0026-0495(96)90040-2

13. Nielsen S, Guo Z, Johnson CM, Hensrud DD, Jensen MD. Splanchnic lipolysis in human obesity. J Clin Invest (2004) 113(11):1582-8. doi:10.1172/ JCI2 1047

14. Rosenbaum M, Pietrobelli A, Vasselli JR, Heymsfield SB, Leibel RL. Sexual dimorphism in circulating leptin concentrations is not accounted for by differences in adipose tissue distribution. Int J Obes Relat Metab Disord (2001) 25(9):1365-71. doi:10.1038/sj.ijo.0801730

15. Sandoval DA, Davis SN. Leptin: metabolic control and regulation. J Diabetes Complications (2003) 17(2):108-13. doi:10.1016/S1056-8727(02)00167-8 hypoglycemia were similar to fasting: women's reliance on lipolysis was higher and carbohydrates lower. Surprisingly, women appeared to be resistant to the blunting effect of repeated hypoglycemia, which abolished the greater neuroendocrine and ANS responses usually observed in men during hypoglycemia.

Autonomic nervous system responses were increased in men relative to women across a broad spectrum of submaximal exercise intensities. Exercise intensity and duration as well as endurance training also resulted in increased carbohydrate oxidation in men but greater lipid utilization in women.

The mechanisms that trigger these differences could include: (1) sexually dimorphic fat distribution, (2) estrogen's effect on circulating catecholamines, (3) gender-based differences in epinephrine sensitivity, and (4) differences in CNS drive in triggering gender-specific neuroendocrine, ANS, and metabolic responses.

16. Jensen MD, Hensrud D, O'Brien PC, Nielsen S. Collection and interpretation of plasma leptin concentration data in humans. Obes Res (1999) 7(3):241-5. doi:10.1002/j.1550-8528.1999.tb00402.x

17. Karakelides H, Irving BA, Short KR, O'Brien P, Nair KS. Age, obesity, and sex effects on insulin sensitivity and skeletal muscle mitochondrial function. Diabetes (2010) 59(1):89-97. doi:10.2337/db09-0591

18. Hoeg L, Roepstorff C, Thiele M, Richter EA, Wojtaszewski JF, Kiens B. Higher intramuscular triacylglycerol in women does not impair insulin sensitivity and proximal insulin signaling. J Appl Physiol (2009) 107(3):824-31. doi:10.1152/ japplphysiol.91382.2008

19. Vistisen B, Hellgren LI, Vadset T, Scheede-Bergdahl C, Helge JW, Dela F, et al. Effect of gender on lipid-induced insulin resistance in obese subjects. Eur J Endocrinol (2008) 158(1):61-8. doi:10.1530/EJE-07-0493

20. Borissova AM, Tankova T, Kirilov G, Koev D. Gender-dependent effect of ageing on peripheral insulin action. Int J Clin Pract (2005) 59(4):422-6. doi:10. 1111/j.1368-5031.2005.00209.x

21. Sumner AE, Kushner H, Sherif KD, Tulenko TN, Falkner B, Marsh JB. Sex differences in African-Americans regarding sensitivity to insulin's glucoregulatory and antilipolytic actions. Diabetes Care (1999) 22(1):71-7. doi:10.2337/diacare. 22.1.71

22. Nuutila P, Knuuti MJ, Maki M, Laine H, Ruotsalainen U, Teras M, et al. Gender and insulin sensitivity in the heart and in skeletal muscles. Studies using positron emission tomography. Diabetes (1995) 44(1):31-6. doi:10.2337/ diabetes.44.1.31

23. Valdes CT, Elkind-Hirsch KE. Intravenous glucose tolerance test-derived insulin sensitivity changes during the menstrual cycle. J Clin Endocrinol Metab (1991) 72(3):642-6. doi:10.1210/jcem-72-3-642

24. Escalante Pulido JM, Alpizar Salazar M. Changes in insulin sensitivity, secretion and glucose effectiveness during menstrual cycle. Arch Med Res (1999) 30(1):19-22. doi:10.1016/S0188-0128(98)00008-6

25. Hoeg LD, Sjoberg KA, Jeppesen J, Jensen TE, Frosig C, Birk JB, et al. Lipidinduced insulin resistance affects women less than men and is not accompanied by inflammation or impaired proximal insulin signaling. Diabetes (2011) 60(1):64-73. doi:10.2337/db10-0698

26. Shadid S, Kanaley JA, Sheehan MT, Jensen MD. Basal and insulin-regulated free fatty acid and glucose metabolism in humans. Am J Physiol Endocrinol Metab (2007) 292(6):E1770-4. doi:10.1152/ajpendo.00655.2006

27. Rattarasarn C, Leelawattana R, Soonthornpun S, Setasuban W, Thamprasit A Gender differences of regional abdominal fat distribution and their relationships with insulin sensitivity in healthy and glucose-intolerant Thais. J Clin Endocrinol Metab (2004) 89(12):6266-70. doi:10.1210/jc.2004-0209

28. Perseghin G, Scifo P, Pagliato E, Battezzati A, Benedini S, Soldini L, et al. Gender factors affect fatty acids-induced insulin resistance in nonobese humans: effects of oral steroidal contraception. J Clin Endocrinol Metab (2001) 86(7):3188-96. doi:10.1210/jcem.86.7.7666

29. Frias JP, Macaraeg GB, Ofrecio J, Yu JG, Olefsky JM, Kruszynska YT. Decreased susceptibility to fatty acid-induced peripheral tissue insulin resistance in women. Diabetes (2001) 50(6):1344-50. doi:10.2337/diabetes.50.6.1344 
30. Donahue RP, Prineas RJ, DeCarlo Donahue R, Bean JA, Skyler JS. The female 'insulin advantage' in a biracial cohort: results from the Miami Community Health Study. Int J Obes Relat Metab Disord (1996) 20(1):76-82.

31. Yki-Jarvinen H. Sex and insulin sensitivity. Metabolism (1984) 33(11):1011-5. doi:10.1016/0026-0495(84)90229-4

32. DeFronzo RA, Tobin JD, Andres R. Glucose clamp technique: a method for quantifying insulin secretion and resistance. Am J Physiol (1979) 237(3):E214-23.

33. Davis SN, Shavers C, Costa F. Differential gender responses to hypoglycemia are due to alterations in CNS drive and not glycemic thresholds. Am J Physiol Endocrinol Metab (2000) 279(5):E1054-63.

34. Davis SN, Cherrington AD, Goldstein RE, Jacobs J, Price L. Effects of insulin on the counterregulatory response to equivalent hypoglycemia in normal females. Am J Physiol (1993) 265(5 Pt 1):E680-9.

35. Sandoval DA, Ertl AC, Richardson MA, Tate DB, Davis SN. Estrogen blunts neuroendocrine and metabolic responses to hypoglycemia. Diabetes (2003) 52(7):1749-55. doi:10.2337/diabetes.52.7.1749

36. Davis SN, Shavers C, Costa F. Gender-related differences in counterregulatory responses to antecedent hypoglycemia in normal humans. J Clin Endocrinol Metab (2000) 85(6):2148-57. doi:10.1210/jcem.85.6.6641

37. Davis SN, Fowler S, Costa F. Hypoglycemic counterregulatory responses differ between men and women with type 1 diabetes. Diabetes (2000) 49(1):65-72. doi:10.2337/diabetes.49.1.65

38. Diamond MP, Jones T, Caprio S, Hallarman L, Diamond MC, Addabbo M, et al. Gender influences counterregulatory hormone responses to hypoglycemia. Metabolism (1993) 42(12):1568-72. doi:10.1016/0026-0495(93)90152-E

39. Amiel SA, Maran A, Powrie JK, Umpleby AM, Macdonald IA. Gender differences in counterregulation to hypoglycaemia. Diabetologia (1993) 36(5):460-4. doi:10.1007/BF00402284

40. Vathy I, Etgen AM. Ovarian steroids and hypothalamic norepinephrine release: studies using in vivo brain microdialysis. Life Sci (1988) 43(19):1493-9. doi:10. 1016/0024-3205(88)90396-7

41. de Miguel R, Fernandez-Ruiz JJ, Hernandez ML, Ramos JA. Role of ovarian steroids on the catecholamine synthesis and release in female rat adrenal: in vivo and in vitro studies. Life Sci (1989) 44(25):1979-86. doi:10.1016/0024-3205(89) 90411-6

42. Nielsen S, Guo Z, Albu JB, Klein S, O’Brien PC, Jensen MD. Energy expenditure, sex, and endogenous fuel availability in humans. J Clin Invest (2003) 111(7):981-8. doi:10.1172/JCI16253

43. Horton TJ, Miller EK, Bourret K. No effect of menstrual cycle phase on glycerol or palmitate kinetics during 90 min of moderate exercise. J Appl Physiol (2006) 100(3):917-25. doi:10.1152/japplphysiol.00491.2005

44. Schmidt SL, Bessesen DH, Stotz S, Peelor FF III, Miller BF, Horton TJ. Adrenergic control of lipolysis in women compared with men. J Appl Physiol (2014) 117(9):1008-19. doi:10.1152/japplphysiol.00003.2014

45. Davis SN, Galassetti P, Wasserman DH, Tate D. Effects of gender on neuroendocrine and metabolic counterregulatory responses to exercise in normal man. J Clin Endocrinol Metab (2000) 85(1):224-30. doi:10.1210/jcem.85.1.6328

46. Mittendorfer B, Horowitz JF, Klein S. Effect of gender on lipid kinetics during endurance exercise of moderate intensity in untrained subjects. Am J Physiol Endocrinol Metab (2002) 283(1):E58-65. doi:10.1152/ajpendo.00504.2001
47. Steffensen CH, Roepstorff C, Madsen M, Kiens B. Myocellular triacylglycerol breakdown in females but not in males during exercise. Am J Physiol Endocrinol Metab (2002) 282(3):E634-42. doi:10.1152/ajpendo.00078.2001

48. Roepstorff C, Donsmark M, Thiele M, Vistisen B, Stewart G, Vissing K, et al. Sex differences in hormone-sensitive lipase expression, activity, and phosphorylation in skeletal muscle at rest and during exercise. Am J Physiol Endocrinol Metab (2006) 291(5):E1106-14. doi:10.1152/ajpendo.00097.2006

49. Roepstorff C, Steffensen CH, Madsen M, Stallknecht B, Kanstrup IL, Richter EA, et al. Gender differences in substrate utilization during submaximal exercise in endurance-trained subjects. Am J Physiol Endocrinol Metab (2002) 282(2):E435-47. doi:10.1152/ajpendo.00266.2001

50. Horton TJ, Pagliassotti MJ, Hobbs K, Hill JO. Fuel metabolism in men and women during and after long-duration exercise. J Appl Physiol (1998) 85(5):1823-32.

51. Carter SL, Rennie C, Tarnopolsky MA. Substrate utilization during endurance exercise in men and women after endurance training. Am J Physiol Endocrinol Metab (2001) 280(6):E898-907.

52. Devries MC, Hamadeh MJ, Phillips SM, Tarnopolsky MA. Menstrual cycle phase and sex influence muscle glycogen utilization and glucose turnover during moderate-intensity endurance exercise. Am J Physiol Regul Integr Comp Physiol (2006) 291(4):R1120-8. doi:10.1152/ajpregu.00700.2005

53. Kendrick ZV, Ellis GS. Effect of estradiol on tissue glycogen metabolism and lipid availability in exercised male rats. J Appl Physiol (1991) 71(5): 1694-9.

54. Rooney TP, Kendrick ZV, Carlson J, Ellis GS, Matakevich B, Lorusso SM, et al. Effect of estradiol on the temporal pattern of exercise-induced tissue glycogen depletion in male rats. J Appl Physiol (1993) 75(4):1502-6.

55. Friedlander AL, Casazza GA, Horning MA, Huie MJ, Piacentini MF, Trimmer JK, et al. Training-induced alterations of carbohydrate metabolism in women: women respond differently from men. J Appl Physiol (1998) 85(3):1175-86.

56. Tarnopolsky LJ, MacDougall JD, Atkinson SA, Tarnopolsky MA, Sutton JR. Gender differences in substrate for endurance exercise. J Appl Physiol (1990) 68(1):302-8.

57. Wahrenberg H, Bolinder J, Arner P. Adrenergic regulation of lipolysis in human fat cells during exercise. Eur J Clin Invest (1991) 21(5):534-41. doi:10.1111/j. 1365-2362.1991.tb01406.x

58. Arner P, Kriegholm E, Engfeldt P, Bolinder J. Adrenergic regulation of lipolysis in situ at rest and during exercise. J Clin Invest (1990) 85(3):893-8. doi:10.1172/ JCI114516

Conflict of Interest Statement: The authors declare that the research was conducted in the absence of any commercial or financial relationships that could be construed as a potential conflict of interest.

Copyright (C) 2015 Hedrington and Davis. This is an open-access article distributed under the terms of the Creative Commons Attribution License (CC BY). The use, distribution or reproduction in other forums is permitted, provided the original author(s) or licensor are credited and that the original publication in this journal is cited, in accordance with accepted academic practice. No use, distribution or reproduction is permitted which does not comply with these terms. 